\author{
Slawomir Kurek, Tomasz Rachwał \\ Uniwersytet Pedagogiczny \\ im. Komisji Edukacji Narodowej \\ w Krakowie
}

\title{
Założenia i wstępne wyniki europejskiego projektu badawczego FIFOBI w zakresie kształtowania kompetencji uczniów gimnazjum do prowadzenia dzialalności gospodarczej
}

Powszechnie przyjmuje się, że przedsiębiorczość, rozumiana zarówno bardzo szeroko, jako postawa człowieka aktywnego, zdolnego do czynnego uczestnictwa w życiu społeczno-gospodarczym (Brzozowski 2007; Rachwał 2005), jak i w nieco węższym zakresie, jako gotowość i zdolność do założenia i prowadzenia własnego przedsiębiorstwa (Maślanka 2006), jest jednym z podstawowych czynników rozwoju społeczno-gospodarczego układów przestrzennych różnej skali (Zioło 2006; Zioło, Rachwał 2005). To właśnie działalność różnego typu przedsiębiorstw: od mikroprzedsiębiorstw, wśród których dużą rolę odgrywają jednoosobowe prywatne firmy (Kamińska 2006; Zioło, Kamińska 1993; Zioło, Piróg 2000) przez przedsiębiorstwa małej i średniej wielkości (Pach 2008; Surdej 2003; Surdej, Wach, 2007; Wach 2007), aż po duże przedsiębiorstwa krajowe i korporacje międzynarodowe (Kilar 2009; Gierańczyk 2006; Rachwał 2005; Rachwał, Wiedermann, 2008; Śleszyński 2007; Tobolska 2004; Zioło 2001), kształtuje gospodarkę układów lokalnych, regionalnych i krajowych oraz wpływa na przemiany gospodarki światowej. Rozwój przedsiębiorczości jest uważany za szczególnie ważny czynnik wzrostu gospodarczego w krajach transformujących swoje gospodarki, szczególnie w Polsce oraz innych krajach Europy Środkowej i Wschodniej (Gierańczyk 2009; Kurek, Rachwał 2010).

Jednocześnie współczesne tendencje rozwoju cywilizacyjnego, związane z budową gospodarki opartej na wiedzy oraz kształtowaniem społeczeństwa informacyjnego (Borowiec 2008; Borowiec, Dorocki, Jenner 2009; Gierańczyk 2009; Kilar 2008; Zioło 2005), wymagają stałej modernizacji procesu dydaktycznego na wszystkich poziomach edukacyjnych. Jest to potrzebne po to, aby dostosować cele i treści kształcenia szkolnego do wyzwań związanych z przygotowaniem społeczeństwa, w tym młodego pokolenia, do życia we współczesnym świecie (Górz, Rachwał 2006; Rachwał, Kudełko, Tracz, Wach, Kilar 2008; Rachwał 2004; Wach 2007). Szczególną rolę odgrywa tu edukacja ekonomiczna. Jej znaczenie uwidacznia się w sposób wyjątkowy w warunkach trwającego kryzysu gospodarczego, którego pierwsze objawy dało się zaobserwować na początku 2008 roku. W warunkach ograniczania produkcji i poziomu zatrudnienia, co wpływa na powiększenie się rozmiarów bezrobocia, duże znaczenie ma zdolność każdego człowieka do stawienia czoła tym trudnościom. Zdolność ta wynika nie tylko z indywidualnych, wrodzonych predyspozycji związanych z określonymi cechami osobowości, ale jest też efektem kształtowania postaw przedsiębiorczych w toku edukacji szkolnej. Pozwala to w warunkach wysokiego bezrobocia i trudności ze znalezieniem pracy na podjęcie samozatrudnienia i rozwój własnego biznesu (Kurek, Rachwał 2010; Rachwał 2010). 
Należy jednak zwrócić uwagę na powszechnie zauważany (zarówno przez pracodawców, jak i specjalistów od rynku pracy) fakt braku dostatecznych kompetencji absolwentów szkół do podjęcia pracy i samozatrudnienia, wynikający z niedostatecznego wyposażenia w wiedzę i umiejętności związane $\mathrm{z}$ funkcjonowaniem w świecie biznesu. Bierze się to m.in. z faktu ograniczenia w XX wieku edukacji ekonomicznej w większości krajów europejskich w szkolnictwie wyższym, ewentualnie wyższym średnim (szkołach ponadgimnazjalnych), głównie o profilu ekonomicznym. W wielu krajach europejskich podejmowane są więc w ostatnich latach próby przeniesienia edukacji ekonomicznej na niższe poziomy edukacji w ramach kształcenia ogólnego oraz do systemów tzw. kształcenia ustawicznego. Wyniesione z poprzednich lat wykształcenie w tym zakresie jest bowiem niewystarczające bądź uzyskana wiedza i umiejętności mocno się zdezaktualizowały w wyniku przyspieszonych przemian społeczno-gospodarczych na świecie.

Warto również zwrócić uwagę na to, że pomimo nasilających się procesów integracyjnych prowadzących do coraz większej spójności i harmonizacji wielu dziedzin życia społeczno-gospodarczego w krajach członkowskich Unii Europejskiej, nadal występuje duże zróżnicowanie systemów kształcenia w krajach europejskich, przez co kompetencje w zakresie prowadzenia działalności gospodarczej w toku edukacji szkolnej są kształtowane w poszczególnych krajach na różnym poziomie. Przekłada się to na gorsze warunki dostępu części młodzieży do europejskiego rynku pracy, szczególnie z krajów transformujących swoje gospodarki, w których w okresie centralnego sterowania gospodarką ograniczano możliwość rozwoju własnego biznesu i tym samym sukcesji firm. Wpływało to na niższy w porównaniu z krajami zachodnioeuropejskimi stopień przekazywania młodemu pokoleniu doświadczeń rodziców w zakresie umiejętności prowadzania działalności gospodarczej. Wiele krajów podejmuje więc próby reformy systemu edukacji ekonomicznej, związane z obserwowanymi negatywnymi skutkami światowego kryzysu gospodarczego oraz nieprzygotowaniem społeczeństw do stawienia czoła trudnościom. Reformy te związane są także z implementacją Rekomendacji Parlamentu Europejskiego i Komisji Europejskiej w sprawie kompetencji kluczowych, w tym m.in. przedsiębiorczości (Recommendation of the European Parliament... 2006). W związku z tymi - wprowadzanymi bądź planowanymi - reformami systemu edukacji ekonomicznej pojawiło się więc zapotrzebowanie na diagnozy dotychczasowego stanu edukacji związanej z kształtowaniem kompetencji do prowadzenia działalności gospodarczej. Choć w wielu krajach były lub są prowadzone tego typu analizy, zauważa się brak ponadkrajowych programów badawczych, w których zostałyby podjęte próby wypracowania najlepszych praktyk, możliwych do zastosowania w wielu krajach europejskich. Większość programów badawczych w tym zakresie ogranicza się do diagnozy stanu w poszczególnych krajach i propozycji dla systemów edukacyjnych tych państw, bez próby wypracowania rozwiązań, które mogłyby być zaimplementowane na poziomie całej Unii Europejskiej bądź w innych krajach członkowskich.

\section{Założenia projektu}

Odpowiedzią na to zapotrzebowanie ze strony oświaty jest europejski projekt badawczy FIFOBI - Fit for Business: Developing Business Competencies in School (Zdolni do biznesu: ksztattowanie kompetencji biznesowych uczniów) o numerze 143356-LLP-1-2008-1-DEKA1-KA1SCR. Jego realizacja jest możliwa dzięki dofinansowaniu ze środków unijnych ze strony Komisji Europejskiej - Agencji Wykonawczej ds. Edukacji, Kultury i Sektora Audiowizualnego w ramach Programu Kształcenia Ustawicznego (Lifelong Learning Programme). 
W wyniku realizacji projektu zostaną zbadane aktualne zapisy podstawy programowej i programy nauczania ${ }^{1}$ realizowane $\mathrm{w}$ dwóch ostatnich latach obowiązkowej edukacji (w Polsce - gimnazjum), dotyczące kształtowania kompetencji w zakresie prowadzenia biznesu oraz kształcenia przedzawodowego (przygotowawczego do wykonywania zawodu) w różnych krajach biorących udział w tym projekcie. Ta analiza porównawcza, poparta badaniami opinii osób kluczowych w systemie edukacji (nauczycieli, przedstawicieli pracodawców itp.) pozwoli zidentyfikować mocne punkty i słabe strony w obrębie każdego krajowego systemu edukacji w celu promowania tzw. najlepszej praktyki (best practice). Ostatecznie projekt ten powinien pozwolić na zbudowanie innowacyjnego modelu do naśladowania oraz pomóc w stworzeniu bazy dla budowy strategii kształcenia przez całe życie (lifelong learning), a także kształcenia na wyższych poziomach edukacji.

Planowany okres działań projektowych to styczeń 2009 - grudzień 2011. W jego realizacji uczestniczą przedstawiciele 11 instytucji partnerskich z 7 krajów Unii Europejskiej, tj.:

1. Niemcy (lider projektu, kierownik - prof. Matthias Pilz)

- Universität zu Köln (University of Cologne)

- Pädagogische Hochschule Freiburg (University of Education, Freiburg)

- Landesschulbehörde Standort Hannover

2. Polska

- Uniwersytet Pedagogiczny w Krakowie - Instytut Geografii ${ }^{2}$

3. Austria

- Kirchliche Pädagogische Hochschule in Wien

- International Bilingual Business College Hetzendorf (Wien)

4. Łotwa

- Rīgas Pedagoǵijas un izglītîbas vadības augstskola (Riga Teacher Training and Educational Management Academy)

5. Portugalia

- ACADEMUS - Consultadoria, Formação e Investigação Lda

6. Węgry

- EduNet Tananyagfejlesztesi Alapitvany (EduNet Foundation for New Educational Resources)

7. Wielka Brytania

- University of Stirling

- North Lanarkshire Council, Learning \& Leisure Services.

Przy doborze partnerów do projektu wzięto pod uwagę konieczność uczestniczenia w nim nie tylko środowisk akademickich (uniwersytetów), ale także instytucji edukacyjnych, pozarządowych organizacji społecznych (fundacja) oraz przedsiębiorstw (spółka „Academus”). Analizy prowadzone w ramach projektu koncentrują się na trzech obszarach:

\footnotetext{
${ }^{1}$ Należy zwrócić uwagę na to, że w Polsce od roku szkolnego 2009/2010 zmieniono zasady dopuszczania programów nauczania do realizacji w szkole. Zgodnie z nowym Rozporządzeniem MEN (2009) obecnie programy nie są już zatwierdzane przez ministra właściwego do spraw oświaty i wychowania w oparciu o opinię recenzentów ministerialnych, ale przez dyrektora szkoły, po zasięgnięciu opinii rady pedagogicznej. Nie wyklucza to jednak opracowywania programów autorskich przez poszczególnych autorów (głównie autorów podręczników) jako propozycji do wykorzystania przez nauczycieli. W pracy badawczej przez zespół polski zostaną poddane ocenie wybrane programy przygotowane przez zespoły autorskie wiodących wydawców podręczników szkolnych.

${ }^{2} \mathrm{~W}$ projekcie ze strony polskiej uczestniczą następujący pracownicy IG UP: dr T. Rachwał - Zakład Przedsiębiorczości i Gospodarki Przestrzennej (kierownik ze strony partnera polskiego), dr hab. S. Kurek - Zakład Geografii Społeczno-Ekonomicznej, dr M. Szubert - Zakład Turystyki i Badań Regionalnych.
} 
- identyfikacji umiejętności i wiedzy zdobywanej przez uczących się z zakresu ekonomii i biznesu,

- ustaleniu zakresu, w jakim odpowiedzialność osobista (za swoje decyzje, wybory, działania) i myślenie przedsiębiorcze jest kształtowana w szkołach,

- identyfikacji podstawowych kompetencji społecznych, jakie są kształtowane w nauczaniu młodych ludzi w kontekście umiejętności zawodowych (przygotowania ich do wykonywania pracy, w tym we własnej firmie).

Praca badawcza obejmuje następujące etapy:

1. analizę porównawczą podstawy programowej kształcenia ogólnego i programów nauczania w poszczególnych krajach opartą na uzgodnionych wspólnie kryteriach (ekonomicznych, biznesowych i społecznych/interpersonalnych),

2. analizę opinii nauczycieli, w oparciu o przeprowadzone wywiady w szkołach, w celu ustalenia, jak edukacja ekonomiczna (biznesowa i przedzawodowa) jest organizowana w szkołach, identyfikacji potencjalnych problemów w realizacji programów nauczania z tego zakresu oraz zakresu istniejących kontaktów utrzymywanych przez szkołę z rynkiem pracy,

3. analizę opinii kluczowych przedstawicieli rynku pracy: przeprowadzone zostaną wywiady z przedstawicielami związków pracodawców i związków zawodowych w celu oceny relacji pomiędzy szkołą a światem biznesu i zawieranych umów o współpracy, mających na celu podniesienie efektywności kształcenia ekonomicznego i przygotowania uczniów do wejścia na rynek pracy.

Celem aplikacyjnym badań jest rozwinięcie koncepcji ram współpracy w zakresie porównania i wykrycia różnic w poszczególnych programach nauczania w obrębie i pomiędzy krajami, co zmierzać będzie do zidentyfikowania obszarów tzw. najlepszej praktyki, która mogłaby być wykorzystana jako podstawa dla krajowych i międzynarodowych badań porównawczych. Projekt powinien więc przyczynić się do niwelacji dostrzeżonych słabości i przeciwdziałaniu trudnościom we wprowadzaniu efektywnego kształcenia w zakresie edukacji ekonomicznej w trakcie obowiązkowej nauki szkolnej. Trwałym efektem realizacji projektu będzie wspólny raport końcowy, przekazany kluczowym osobom odpowiedzialnym za kształt edukacji ekonomicznej w poszczególnych krajach Unii Europejskiej i na poziomie instytucji europejskich. Ponadto rezultaty projektu obejmą: publikacje opracowań naukowych, w tym postaci elektronicznej, oraz uczestnictwo w krajowych i międzynarodowych konferencjach w celu rozpowszechniania rezultatów projektu.

Z przyjętych celów i zakresu pracy badawczej wynikają zadania poszczególnych partnerów projektu, które obejmują:

- opracowanie kryteriów do badania kompetencji w zakresie edukacji ekonomicznej w gimnazjum na poziomie krajowym i międzynarodowym (w tym wspólnego systemu identyfikowania zapisów wg kodów),

- analizę podstawy programowej i odpowiednich programów nauczania (z różnych przedmiotów) w ostatnich dwóch latach obowiązkowej edukacji,

- przeprowadzenie wywiadów z nauczycielami w zakresie realizacji treści ekonomicznych i kształtowania postaw przedsiębiorczych oraz powiązań z rynkiem pracy,

- podjęcie kontaktów z pracodawcami, organizacjami pracodawców i związkami zawodowymi i przeprowadzenie z nimi wywiadów w zakresie włączania ich we współpracę ze szkołami,

- ocenę podejść badawczych na szczeblu krajowym w celu określenia ich specyfiki, aby możliwe były porównania międzynarodowe, 
- ocenę i porównanie krajowych wyników na poziomie międzynarodowym i wybranie najlepszych działań w tym zakresie, opracowanie rekomendacji dla rozwiązań krajowych i polityki edukacyjnej UE,

- rozpowszechnienie krajowych i międzynarodowych rezultatów projektów przez opracowanie raportów i publikacji zarówno w języku angielskim, jak i narodowym, informowanie kluczowych instytucji odpowiedzialnych za system edukacji przez rozpowszechnianie informacji i organizowanie warsztatów oraz wspieranie procesów innowacyjnych w oświacie w tym zakresie.

\section{Wstępne wyniki}

W 2009 roku rozpoczęto realizację I etapu prac, tj. opracowano kryteria i rozpoczęto analizę podstawy programowej kształcenia ogólnego w ostatnich dwóch latach obowiązkowej edukacji (w Polsce - gimnazjum). Analiza zapisów podstawy programowej i programów nauczania w zakresie kształtowania kompetencji biznesowych obejmuje cztery grupy kryteriów, z zakresu:

- wiedzy ekonomicznej,

- wiedzy i umiejętności związanych z prowadzeniem działalności gospodarczej,

- umiejętności (kompetencji) społecznych,

- umiejętności osobistych (self-competencies), ze szczególnym naciskiem na postawę przedsiębiorczości.

Z zakresu wiedzy ekonomicznej kryteria oceny zapisów podstawy programowej i programów nauczania obejmują następujące treści:

- główne zasady ekonomii, rozumienie ekonomii jako nauki o tym, jak społeczeństwo zarządza swoimi ograniczonymi zasobami, rozumienie podstawowych zjawisk ekonomicznych $(\operatorname{kod} \mathrm{E} 1)$,

- mechanizm popytu i podaży (E2),

- handel międzynarodowy i procesy globalizacji (E3),

- aktorzy rynku (konsumenci, producenci) (E4),

- system finansowy (oszczędzanie, inwestowanie) (E5),

- polityka ekonomiczna rządu i jej oddziaływanie na gospodarkę (w tym system podatkowy) (E6),

- formy rynku (doskonała konkurencja, oligopol, monopol) (E7),

- firmy jako podmioty gospodarki rynkowej (E8),

- dochód (E9),

- wskaźniki gospodarcze (E10),

- rynek pracy (w tym bezrobocie) (E11).

Kryteria oceny wiedzy i umiejętności z zakresu prowadzenia działalności gospodarczej obejmuja:

- biznes i jego zewnętrzne otoczenie (B1),

- strategię przedsiębiorstwa i planowanie (B2),

- organizowanie (struktura organizacji i jej poziomy, znaczenie kierownictwa, odpowiedzialność i jej przekazywanie na niższe szczeble zarządzania) (B3),

- kierowanie (przywództwo, relacje i komunikacja pomiędzy menadżerami i zatrudnionymi) (B4),

- kontrolowanie i zasady księgowania (rachunkowości) (B5),

- marketing i zarządzanie sprzedażą (B6),

- zarządzanie produkcją (operacyjne) (B7),

- zasobami ludzkimi (B8), 
- administrowanie (zarządzanie administracja) (B9).

Natomiast kryteria społeczne obejmuja:

- zdolność komunikacji (SO1),

- zdolność do rozpoznawania i rozwiązywania konfliktów (SO2),

- zdolność do udzielania i przyjmowania uwag krytycznych (SO3),

- umiejętność pracy w zespole (SO4),

- empatię (SO5).

Kryteria oceny realizacji treści programowych z zakresu kompetencji osobistych (self-competencies) związanych z postawą przedsiębiorczą obejmują:

- umiejętność kontroli wewnętrznej (wiara w możliwość kontrolowania swojego działania i przekonanie, że zdarzenia są głównie wynikiem własnego zachowania i działania) (SE1),

- zdolność do motywowania samego siebie (automotywacji) - ustanawiania celów działania dla siebie (SE2),

- pragnienie niezależności (jako element autonomii jednostki i samospełnienia) (SE3),

- tendencję do podejmowania umiarkowanego (przemyślanego) ryzyka (SE4).

Ze względu na duże zróżnicowanie systemów edukacyjnych w poszczególnych krajach i związane z tym różnice zapisów podstawy programowej i programów nauczania dopuszcza się możliwość rozszerzenia powyższych zapisów o kryteria, które wynikają ze specyfiki edukacji ekonomicznej w poszczególnych krajach.

Wyniki analizy zapisów nowej podstawy programowej kształcenia ogólnego w świetle Rozporzqdzenia MEN z 12 grudnia 2008 r. (realizowanej na tym poziomie edukacji od roku szkolnego 2009/2010) wskazuja, że kształtowanie kompetencji biznesowych (w szerokim rozumieniu, wg kryteriów projektu) odbywa się przede wszystkim w ramach przedmiotu wiedza o społeczeństwie (WOS), ale także w ramach zajęć z matematyki (M), języka polskiego (JP) i wychowania do życia w rodzinie (WŻR) - tab. 1, 2, 3, 4. Należy jednak zauważyć, że także treści kształcenia z zakresu geografii można częściowo uznać za związane z kształtowaniem kompetencji biznesowych. Uznano jednak, że dyskusyjne wydaje się zaliczenie części wymagań z geografii (np. „charakteryzuje szybki rozwój gospodarczy Niemiec”, „rozwój usług w Polsce”, ,gospodarka Australii” czy „rolnictwo Francji lub innego kraju europejskiego”) do zakresu objętego analiza, dlatego we wstępnej fazie treści te nie zostają zaliczone do żadnej z wyróżnionych grup kryteriów, przy czym problem ten będzie jeszcze przedmiotem dyskusji na kolejnym międzynarodowym spotkaniu roboczym grupy badawczej.

Analiza zapisów podstawy programowej wskazuje, że szkoła powinna stosunkowo dobrze wyposażać uczniów w wiedzę ekonomiczną (tab. 1). Do istotnych braków w zapisach podstawy programowej należy zaliczyć treści związane z formami rynku (E7).

Kompetencje biznesowe $\mathrm{w}$ wąskim rozumieniu, tj. bezpośrednio związane z przygotowaniem do prowadzenia działalności gospodarczej, w świetle podstawy programowej są również realizowane, niestety w bardzo ograniczonym zakresie, w ramach przedmiotu wiedza o społeczeństwie (tab. 2). Do istotnych braków w zapisach podstawy programowej należy zaliczyć treści związane $\mathrm{z}$ budową strategii przedsiębiorstwa (B2), kierowaniem ludźmi, w tym przywództwem oraz relacjami i komunikacją pomiędzy menadżerami i zatrudnionymi (B4), gdyż zapisy podstawy programowej ograniczają się tylko do kwestii etycznych w tym zakresie. Brak jest zupełnie treści kształcenia związanych z kontrolowaniem i zasadami księgowości (rachunkowości) (B5), zarządzaniem produkcją (B7) i administracją (B9). Na uwagę zasługuje także znaczne ograniczenie treści związanych z zarządzaniem zasobami ludzkimi. Zapisy treści programowych rozszerzono natomiast o zagadnienia dotyczące szarej strefy i korupcji, które, ze względu na duże znaczenie tej problematyki we współczesnej gospodarce, wyróżniono jako dodatkowe kryterium (B10). 
Tab. 1. Zapisy podstawy programowej kształcenia ogólnego w gimnazjum dotyczące wiedzy ekonomicznej

\begin{tabular}{|c|c|}
\hline Kryterium & Treści nauczania wg podstawy programowej \\
\hline E1 & $\begin{array}{l}\text { - WOS } 24.1 \text { wyjaśnia na przykładach z życia własnej rodziny, miejscowości i całego kraju, w jaki } \\
\text { sposób praca i przedsiębiorczość pomagają w zaspokajaniu potrzeb ekonomicznych }\end{array}$ \\
\hline E2 & $\begin{array}{l}\text { - WOS } 25.3 \text { charakteryzuje gospodarkę rynkową (prywatna własność, swoboda gospodarowania, } \\
\text { konkurencja, dażenie do zysku, przedsiębiorczość); } \\
\text { • WOS } 25.4 \text { wyjaśnia działanie prawa podaży i popytu oraz ceny jako regulatora rynku; analizuje } \\
\text { rynek wybranego produktu i wybranej usługi }\end{array}$ \\
\hline E3 & $\begin{array}{l}\text { - WOS } 23.3 \text { wyjaśnia, odwołując się do przykładów, na czym polega globalizacja w sferze kultury, } \\
\text { gospodarki i polityki; ocenia jej skutki }\end{array}$ \\
\hline E4 & $\begin{array}{l}\text { - WOS } 25.1 \text { przedstawia podmioty gospodarcze (gospodarstwa domowe, przedsiębiorstwa, } \\
\text { państwo) i związki między nimi; } \\
\text { - WOS } 26.1 \text { wyjaśnia na przykładach, jak funkcjonuje gospodarstwo domowe; } \\
\text { - WOS } 26.2 \text { wymienia główne dochody i wydatki gospodarstwa domowego; układa jego budżet; } \\
\text { • WOS } 26.3 \text { przygotowuje budżet konkretnego przedsięwzięcia z życia ucznia, klasy, szkoły; } \\
\text { rozważa wydatki i źródła ich finansowania; } \\
\text {-WOS } 26.4 \text { wyjaśnia, jakie prawa mają konsumenci i jak mogą dochodzić tych praw }\end{array}$ \\
\hline E5 & $\begin{array}{l}\text { - WOS } 25.2 \text { podaje przykłady racjonalnego i nieracjonalnego gospodarowania; stosuje zasady } \\
\text { racjonalnego gospodarowania w odniesieniu do własnych zasobów (np. czasu, pieniędzy); } \\
\text { - WOS } 27.1 \text { przedstawia na przykładach funkcje i formy pieniądza w gospodarce rynkowej; } \\
\text { - WOS } 27.2 \text { wyjaśnia, czym zajmują się: bank centralny, banki komercyjne, giełda papierów } \\
\text { - wartościowych; } \\
\text {-WOS } 27.3 \text { wyszukuje i zestawia ze sobą oferty różnych banków (konta, lokaty, kredyty, } \\
\text { fundusze inwestycyjne); wyjaśnia, na czym polega oszczędzanie i inwestowanie; } \\
\text { - M 5.4 stosuje obliczenia procentowe do rozwiązywania problemów w kontekście praktycznym, } \\
\text { np. oblicza ceny po podwyżce lub obniżce o dany procent, wykonuje obliczenia związane } \\
\text { z VAT, oblicza odsetki dla lokaty rocznej }\end{array}$ \\
\hline E6 & $\begin{array}{l}\text { - WOS } 20.4 \text { wyjaśnia, skąd pochodzą środki finansowe w budżecie unijnym i na co są przeznaczane; } \\
\text { • WOS } 21.2 \text { wyszukuje informacje na temat korzystania ze środków unijnych przez polskich } \\
\text { obywateli, przedsiębiorstwa i instytucje; } \\
\text { - WOS } 28.2 \text { wymienia najważniejsze dochody i wydatki państwa; wyjaśnia, co to jest budżet państwa; } \\
\text { • WOS } 28.3 \text { przedstawia główne rodzaje podatków w Polsce (PIT, VAT, CIT) i oblicza wysokość } \\
\text { podatku PIT na podstawie konkretnych danych }\end{array}$ \\
\hline E7 & - \\
\hline E8 & $\begin{array}{l}\text { WOS } 29.2 \text { wyjaśnia, jak działa przedsiębiorstwo, i oblicza na prostym przykładzie przychód, } \\
\text { koszty, dochód i zysk }\end{array}$ \\
\hline E9 & WOS 26.2 wymienia główne dochody i wydatki gospodarstwa domowego; układa jego budżet* \\
\hline E10 & $\begin{array}{l}\text { - WOS } 28.1 \text { wyjaśnia terminy: „produkt krajowy brutto”, „wzrost gospodarczy”, ,,inflacja”, ,,rece- } \\
\text { sja”; interpretuje dane statystyczne na ten temat; } \\
\text { - M } 8.4 \text { odczytuje i interpretuje informacje przedstawione za pomocą wykresów funkcji (w tym } \\
\text { wykresów opisujących zjawiska występujące w przyrodzie, gospodarce, życiu codziennym); } \\
\text { - M } 9.1 \text { interpretuje dane przedstawione za pomocą tabel, diagramów słupkowych i kołowych } \\
\text { oraz wykresów }\end{array}$ \\
\hline E11 & $\begin{array}{l}\text { - WOS } 30.2 \text { wyszukuje informacje o możliwościach zatrudnienia na lokalnym, regionalnym } \\
\text { i krajowym rynku pracy (urzędy pracy, ogłoszenia, internet); } \\
\text { - WOS } 30.3 \text { sporządza życiorys i list motywacyjny; } \\
\text { - WOS } 30.4 \text { wskazuje główne przyczyny bezrobocia w swojej miejscowości, regionie i Polsce; } \\
\text { ocenia jego skutki }\end{array}$ \\
\hline
\end{tabular}

WOS - wiedza o społeczeństwie, M - matematyka. Numery oznaczają punkty podstawy programowej wg Rozporządzenia MEN z 2008 r.; kody - wg kryteriów przedstawionych wyżej.

* punkt WOS 26.2 można zakwalifikować do dwóch kryteriów: E4 i E9.

Źródło: opracowanie własne. 
Tab. 2. Zapisy podstawy programowej kształcenia ogólnego w gimnazjum dotyczące wiedzy i umiejętności związanych z prowadzeniem działalności gospodarczej

\begin{tabular}{|c|c|}
\hline Kryterium & Treści nauczania wg podstawy programowej \\
\hline B1 & $\begin{array}{l}\text { - WOS } 29.1 \text { wyjaśnia, na czym polega prowadzenie indywidualnej } \\
\text { działalności gospodarczej }\end{array}$ \\
\hline B2 & - \\
\hline B3 & $\begin{array}{l}\text { - WOS } 24.3 \text { stosuje w praktyce podstawowe zasady organizacji } \\
\text { pracy (ustalenie celu, planowanie, podział zadań, harmonogram, } \\
\text { ocena efektów) }\end{array}$ \\
\hline B4 & $\begin{array}{l}\text { - WOS } 31.1 \text { przedstawia zasady etyczne, którymi powinni się } \\
\text { kierować pracownicy i pracodawcy; wyjaśnia, na czym polega } \\
\text { społeczna odpowiedzialność biznesu }\end{array}$ \\
\hline B5 & - \\
\hline B6 & $\begin{array}{l}\text { - WOS } 29.3 \text { wskazuje główne elementy działań marketingowych } \\
\text { (produkt, cena, miejsce, promocja) i wyjaśnia na przykładach } \\
\text { ich znaczenie dla przedsiębiorstwa i konsumentów }\end{array}$ \\
\hline B7 & - \\
\hline B8 & $\begin{array}{l}\text { - WOS } 29.4 \text { przedstawia główne prawa i obowiązki pracownika; } \\
\text { wyjaśnia, czemu służą ubezpieczenia społeczne i zdrowotne }\end{array}$ \\
\hline B9 & - \\
\hline B10 (PL) & $\begin{array}{l}\text { - WOS } 31.2 \text { podaje przykłady zjawisk z szarej strefy w gospodarce } \\
\text { i poddaje je ocenie; } \\
\text { - WOS } 31.3 \text { wyjaśnia mechanizm korupcji i ocenia skutki tego } \\
\text { zjawiska dla gospodarki }\end{array}$ \\
\hline
\end{tabular}

WOS - wiedza o społeczeństwie.

Źródło: opracowanie własne.

Kompetencje społeczne w świetle zapisów podstawy programowej powinny być kształtowane głównie na lekcjach języka polskiego i wychowania do życia w rodzinie (tab. 3). Co może się wydać zaskakujące - zapisów dotyczących tych kompetencji nie można odnaleźć w przedmiocie wiedza o społeczeństwie. Analiza zapisów podstawy wskazuje na to, że dobrze realizowane powinny być treści z zakresu zdolności komunikacji (SO1) oraz rozpoznawania i rozwiązywania konfliktów (SO2). W tym drugim przypadku, ze względu na ich realizację na lekcjach wychowania do życia w rodzinie, rozwiązywanie konfliktów dotyczy relacji dzieci - rodzice, ale można założyć, że uczniowie zdobędą w trakcie lekcji z tym związanych także kompetencje do rozwiązywania konfliktów w swoim przyszłym miejscu pracy. Brak jest natomiast $\mathrm{w}$ podstawie programowej treści nauczania związanych ze zdolnością do udzielania i przyjmowania uwag krytycznych (SO3) oraz empatią (SO5). Za szczególnie istotny brak w zapisach należy uznać brak kształtowania umiejętności pracy w zespole (SO4), która jest kluczowa w warunkach coraz większej specjalizacji, a także rosnącej roli grupowego rozwiązywania skomplikowanych zadań, co ma miejsce praktycznie w każdym środowisku pracy. Na ogromną rolę umiejętności pracy w zespole wskazuje bogata literatura przedmiotu dotycząca 
zarządzania. S. Covey (2003) umiejętność twórczej, synergicznej współpracy w zespole zalicza do jednej z siedmiu podstawowych zasad skutecznego działania każdego człowieka, nie tylko skutecznego menedżera-przywódcy (Covey 2004).

Tab. 3. Zapisy podstawy programowej kształcenia ogólnego w gimnazjum dotyczące kompetencji społecznych

\begin{tabular}{|c|c|}
\hline Kryterium & Treści nauczania wg podstawy programowej \\
\hline SO1 & $\begin{array}{l}\text { - JP I.1.6 rozpoznaje wypowiedzi o charakterze emocjonalnym i perswazyjnym; } \\
\text { - JP I.1.7 rozpoznaje intencje wypowiedzi (aprobatę, dezaprobatę, negację, } \\
\text { prowokacje); } \\
\text { - JP I.1.8 dostrzega w wypowiedzi ewentualne przejawy agresji i manipulacji; } \\
\text { - JP I.1.9 rozpoznaje wypowiedź argumentacyjną, wskazuje tezę, argumenty } \\
\text { i wnioski; } \\
\text { - JP III.1.1 tworzy spójne wypowiedzi ustne (monologowe i dialogowe) oraz pisemne } \\
\text { w następujących formach gatunkowych: (...) dostosowuje odmianę i styl języka } \\
\text { do gatunku, w którym się wypowiada; } \\
\text { - JP III.1.5 uczestniczy w dyskusji, uzasadnia własne zdanie, przyjmuje poglądy } \\
\text { innych lub polemizuje z nimi; } \\
\text { - JP III.1.6 przestrzega zasad etyki mowy w różnych sytuacjach komunikacyjnych, } \\
\text { m.in. zna konsekwencje stosowania form charakterystycznych dla elektronicznych } \\
\text { środków przekazywania informacji, takich jak: SMS, e-mail, czat, blog } \\
\text { (ma świadomość niebezpieczeństwa oszustwa i manipulacji powodowanych } \\
\text { anonimowością uczestników komunikacji w sieci, łatwego obrażania obcych, } \\
\text { ośmieszania i zawstydzania innych wskutek rozpowszechniania obrazów } \\
\text { przedstawiających ich w sytuacjach kłopotliwych, zna skutki kłamstwa, } \\
\text { manipulacji, ironii); } \\
\text { - JP III.1.7 stosuje zasady etykiety językowej - wie, w jaki sposób zwracać się do } \\
\text { rozmówcy w zależności od sytuacji i relacji łączącej go z osobą, do której mówi } \\
\text { (dorosły, rówieśnik, obcy, bliski), zna formuły grzecznościowe, zna konwencje } \\
\text { językowe zależne od środowiska (np. sposób zwracania się do nauczyciela, lekarza, } \\
\text { profesora wyższej uczelni), ma świadomość konsekwencji używania formuł niesto- } \\
\text { sownych i obraźliwych; } \\
\text { - WŻR } 5 \text { zachowania asertywne. }\end{array}$ \\
\hline $\mathrm{SO} 2$ & $\begin{array}{l}\text { - WŻR } 2 \text { Budowa prawidłowych relacji z rodzicami. Konflikt pokoleń; przyczyny } \\
\text { i sposoby rozwiązywania konfliktów. }\end{array}$ \\
\hline $\mathrm{SO} 3$ & - \\
\hline $\mathrm{SO} 4$ & - \\
\hline SO5 & - \\
\hline
\end{tabular}

JP - język polski, WŻR - wychowanie do życia w rodzinie.

Źródło: opracowanie własne.

Analiza zapisów podstawy programowej dotyczących kompetencji osobistych (self-competencies) związanych z przedsiębiorczością wskazuje, że praktycznie nie występują one w treściach nauczania (tab. 4). 
Tab. 4. Zapisy podstawy programowej kształcenia ogólnego w gimnazjum dotyczące kompetencji osobistych (self-competencies) związanych z przedsiębiorczością

\begin{tabular}{|c|c|}
\hline Kryterium & Treści nauczania wg podstawy programowej \\
\hline SE1 & - \\
\hline SE2 & $\begin{array}{l}\text { WOS 30.1 planuje dalszą edukację (w tym wybór szkoły ponadgimnazjalnej), } \\
\text { uwzględniając własne preferencje i predyspozycje }\end{array}$ \\
\hline SE3 & - \\
\hline SE4 & - \\
\hline SE5 (PL) & $\begin{array}{l}\text { WOS 24.2 przedstawia cechy i umiejętności człowieka przedsiębiorczego; bierze } \\
\text { udział w przedsięwzięciach społecznych, które pozwalają je rozwinąc }\end{array}$ \\
\hline
\end{tabular}

Źródło: opracowanie własne.

$\mathrm{Na}$ lekcjach w gimnazjum nie zakłada się więc kształtowania umiejętności kontroli wewnętrznej, tj. wiary w możliwość kontrolowania swojego działania i przekonania, że zdarzenia są głównie wynikiem własnego zachowania i działania (SE1), ważnej zdolności do automotywacji, czyli ustanawiania celów działania dla siebie (SE2), pobudzania pragnienia niezależności (SE3) czy umiejętności podejmowania przemyślanego ryzyka (SE4), choć są to kluczowe elementy decydujące o sukcesie w życiu zawodowym i społecznym każdego człowieka oraz podstawowe cechy człowieka przedsiębiorczego (Brzozowski 2007; Rachwał 2005). Jedynie zapis treści nauczania związany z planowaniem dalszej edukacji można wiązać (choć nie bez wątpliwości) z kształtowaniem postawy przedsiębiorczości. Za podstawową w tym względzie treść nauczania na poziomie szkoły gimnazjalnej w Polsce należy jednak uznać zapis ,,przedstawia cechy i umiejętności człowieka przedsiębiorczego; bierze udział w przedsięwzięciach społecznych, które pozwalają je rozwinąć", który to zapis został wyodrębniony tutaj jako osobne, specyficzne dla polskiej sytuacji kryterium (SE 5). Należy jednak podkreślić, że kryterium to nie znalazło się w przygotowanym zestawie w zespole międzynarodowym, gdyż uznano, że tak oczywiste i proste treści nauczania są realizowane na niższych etapach edukacji (w szkole podstawowej).

Reasumując, należy stwierdzić w świetle przeprowadzonej analizy zapisów nowej podstawy programowej kształcenia w III etapie edukacyjnym (gimnazjum), że uczeń w stosunkowo dobrym stopniu powinien być wyposażony w podstawową wiedzę ekonomiczną. Natomiast zauważalne są istotne braki w zakresie kształtowania kompetencji do prowadzenia własnej działalności gospodarczej, szczególnie w zakresie zarządzania, a także kompetencji społecznych (poza komunikowaniem się - realizowanym na lekcjach języka polskiego), w szczególności związanych z rozwiązywaniem konfliktów i pracą zespołową, oraz kompetencji osobistych, związanych z postawą przedsiębiorczości (zapisy podstawy ograniczają się do planowania dalszej edukacji i omówienia cech osoby przedsiębiorczej). W kolejnym etapie prac badawczych możliwe będzie porównanie wyników analizy polskiej podstawy programowej z wynikami innych krajów oraz ocena, czy braki te są nadrabiane poprzez odpowiednie rozszerzenia treści nauczania $\mathrm{w}$ autorskich programach nauczania. Już teraz należy jednak wskazać, że w zapisach podstawy programowej występują istotne braki, co potwierdza konkluzje z wcześniejszej analizy projektu podstawy programowej (Rachwał 2009) oraz uwagi, 
jakie zgłaszali pod jej kątem doradcy metodyczni i nauczyciele przedsiębiorczości podczas corocznych metodycznych konferencji naukowych poświęconych problematyce przedsiębiorczości, które odbywają się w Krakowie³.

\section{Literatura}

1. Borowiec M., 2008, Rola szkolnictwa wyższego w gospodarce opartej na wiedzy [w:] Rola przedsiębiorczości w gospodarce opartej na wiedzy, Z. Zioło, T. Rachwał (red.), „Przedsiębiorczość Edukacja”, nr 4, wydawnictwo Nowa Era, Zakład Przedsiębiorczości i Gospodarki Przestrzennej IG Akademii Pedagogicznej w Krakowie, Warszawa-Kraków, s. 24-36.

2. Borowiec M., Dorocki S., Jenner B., 2009, Wpływ zasobów kapitału ludzkiego na ksztattowanie społeczeństwa informacyjnego i innowacyjności struktur przemysłowych [w:] Funkcje przemystu w kształtowaniu społeczeństwa informacyjnego, Z. Zioło i T. Rachwał (red.), „Prace Komisji Geografii Przemysłu PTG”, nr 13, Wydawnictwo Naukowe UP, Warszawa-Kraków, s. 95-109.

3. Brzozowski T.T., 2007, Przedsiębiorczość - pojęcie polisemiczne czy niewłaściwie rozumiane? [w:] Rola przedsiębiorczości w aktywizacji gospodarczej, Z. Zioło, T. Rachwał (red.), „Przedsiębiorczość - Edukacja”, nr 3, wydawnictwo Nowa Era, Zakład Przedsiębiorczości i Gospodarki Przestrzennej IG Akademii Pedagogicznej w Krakowie, Warszawa-Kraków, s. 196-203.

4. Covey S.R., 2003, 7 nawyków skutecznego działania, Rebis, Poznań.

5. Covey S.R., 2004, Zasady skutecznego przywództwa, Rebis, Poznań.

6. Gierańczyk W., 2006, Rola przedsiębiorstw w polskiej gospodarce w okresie transformacji ustrojowej [w:] Międzynarodowe uwarunkowania rozwoju przemystu, red. Z. Zioło, T. Rachwał, „Prace Komisji Geografii Przemysłu PTG”, nr 8, Wydawnictwo Naukowe AP, Warszawa-Kraków, s. 91-99.

7. Gierańczyk W., 2009, Rozwój społeczeństwa informacyjnego a przedsiębiorczość w krajach transformujących się [w:] Rola przedsiębiorczości w kształtowaniu społeczeństwa informacyjnego, Z. Zioło, T. Rachwał (red.), „Przedsiębiorczość - Edukacja”, nr 5, wydawnictwo Nowa Era, Zakład Przedsiębiorczości i Gospodarki Przestrzennej IG Uniwersytetu Pedagogicznego w Krakowie, WarszawaKraków, s. 19-36.

8. Górz B., Rachwał T., 2006, Uwagi do projektu zmian podstawy programowej podstaw przedsiębiorczości (zrealizowanej przez ISP na zlecenie MEN) [w:] Rola przedsiębiorczości w podnoszeniu konkurencyjności społeczeństwa i gospodarki, Z. Zioło, T. Rachwał (red.), „Przedsiębiorczość - Edukacja”, nr 2, wydawnictwo Nowa Era, Zakład Przedsiębiorczości i Gospodarki Przestrzennej IG Akademii Pedagogicznej w Krakowie, Warszawa-Kraków, s. 226-235.

9. Kamińska W., 2006, Pozarolnicza indywidualna działalność gospodarcza w Polsce w latach 19882003, Instytut Geografii i Przestrzennego Zagospodarowania im. S. Leszczyckiego PAN, Prace Geograficzne nr 203, Warszawa.

10. Kilar W., 2008, Zatrudnienie w działalności badawczej i rozwojowej jako czynnik rozwoju gospodarki opartej o wiedzę [w:] Rola przedsiębiorczości w gospodarce opartej na wiedzy, Z. Zioło, T. Rachwał (red.), „Przedsiębiorczość - Edukacja”, nr 4, wydawnictwo Nowa Era, Zakład Przedsiębiorczości i Gospodarki Przestrzennej IG Uniwersytetu Pedagogicznego w Krakowie, WarszawaKraków, s. 60-69.

11. Kilar W., 2009, Rola korporacji Apple w ksztaltowaniu spoleczeństwa informacyjnego [w:] Rola przedsiębiorczości w ksztaltowaniu społeczeństwa informacyjnego, Z. Zioło, T. Rachwał (red.), „Przedsiębiorczość - Edukacja”, nr 5, wydawnictwo Nowa Era, Zakład Przedsiębiorczości i Gospodarki Przestrzennej IG Uniwersytetu Pedagogicznego w Krakowie, Warszawa-Kraków, s. 48-56.

12. Kilar W., 2009, Zróżnicowanie potencjatu ekonomicznego światowych korporacji informatycznych [w:] Funkcje przemystu w kształtowaniu społeczeństwa informacyjnego, red. Z. Zioło i T. Rachwał, „Prace Komisji Geografii Przemysłu PTG”, nr 13, Komisja Geografii Przemysłu PTG i Zakład Przedsiębiorczości IG AP w Krakowie, Warszawa-Kraków, s. 110-121.

13. Kurek S., Rachwał T., 2010, The Role of Business Education in the Development of Entrepreneurship in the Member States of the European Union, Europa XXI, Warszawa.

${ }^{3}$ Więcej informacji o konferencjach na stronie internetowej www.przedsiebiorczosc.eu 
14. Pach J., 2008, Znaczenie małych i średnich przedsiębiorstw w Polsce po 2000 r. [w:] Rola przedsiębiorczości w gospodarce opartej na wiedzy, Z. Zioło, T. Rachwał (red.), „Przedsiębiorczość - Edukacja”, nr 4, wydawnictwo Nowa Era, Zakład Przedsiębiorczości i Gospodarki Przestrzennej IG Uniwersytetu Pedagogicznego w Krakowie, Warszawa-Kraków, s. 90-107.

15. Rachwał T., 2004, Cele i treści kształcenia przedsiębiorczości w szkołach ponadgimnazjalnych [w:] Przedsiębiorczość stymulatorem rozwoju gospodarczego, red. J. Brdulak, M. Kulikowski, Instytut Wiedzy SGH, Warszawa, s. 263-270.

16. Rachwał T., 2005, Kształtowanie postaw uczniów na lekcjach przedsiębiorczości [w:] Przedsiębiorczość a współczesne wyzwania cywilizacyjne, Z. Zioło, T. Rachwał (red.), „Przedsiębiorczość - Edukacja”, nr 1, Wydawnictwo MiWa, Zakład Przedsiębiorczości i Gospodarki Przestrzennej IG Akademii Pedagogicznej w Krakowie, Kraków, s. 137-144.

17. Rachwał T., 2005, Podstawy przedsiębiorczości. Słownik, wyd. 2, wydawnictwo Nowa Era, Warszawa.

18. Rachwał T., 2005, Zachowania głównych przedsiębiorstw przemysłowych $w$ strukturze obszaru metropolitalnego [w:] Infrastruktura techniczno-ekonomiczna $w$ obszarach metropolitarnych, red. Z. Makieła, T. Marszał, Biuletyn KPZK PAN, z. 222, Warszawa, s. 158-169.

19. Rachwał T., 2006, Kształtowanie postaw przedsiębiorczych w edukacji szkolnej [w:] Szkoła w nauce i praktyce edukacyjnej, t. II, red. B. Muchacka, Oficyna Wydawnicza „Impuls”, Akademia Pedagogiczna w Krakowie, Kraków, s. 427-434.

20. Rachwał T., 2009, Ocena projektu zmian podstawy programowej podstaw przedsiębiorczości, [w:] Rola przedsiębiorczości w ksztattowaniu społeczeństwa informacyjnego Z. Zioło, T. Rachwał (red.), „Przedsiębiorczość - Edukacja”, nr 5, wydawnictwo Nowa Era, Zakład Przedsiębiorczości i Gospodarki Przestrzennej IG Uniwersytetu Pedagogicznego w Krakowie, Warszawa-Kraków, s. 349-372.

21. Rachwał T., 2010, Entrepreneurship Education as a Growth Stimulus for Family Firms [w:] Exploring the Dynamics of Entrepreneurship, eds. A. Surdej, K. Wach, Adam Marszałek Publishing House, Torun.

22. Rachwał T., Kudełko J., Tracz M., Wach K., Kilar W., 2008, Projekt podstawy programowej kształcenia ogólnego w zakresie rozszerzonym dla liceum ogólnoksztatcacego, liceum profilowanego i technikum z podstaw przedsiębiorczości [w:] Rola przedsiębiorczości w gospodarce opartej na wiedzy, Z. Zioło, T. Rachwał (red.), „Przedsiębiorczość - Edukacja”, nr 4, wydawnictwo Nowa Era, Zakład Przedsiębiorczości i Gospodarki Przestrzennej IG Uniwersytetu Pedagogicznego w Krakowie, Warszawa-Kraków, s. 312-324.

23. Rachwał T., Wiedermann K., 2008, Multiplier effects in regional development: The case of the motor vehicle industry in Silesian voivodeship (Poland), Questiones Geographicae 27B/1, Adam Mickiewicz University Press, Poznań, s. 67-80.

24. Recommendation of the European Parliament and of the Council of 18 December 2006 on key competences for lifelong learning (2006/962/EC), Official Journal of the European Union, L 394, 30.12.2006.

25. Rozporzqdzenie Ministra Edukacji Narodowej z dnia 23 grudnia 2008 r. w sprawie podstawy programowej wychowania przedszkolnego oraz kształcenia ogólnego w poszczególnych typach szkót, DzU 2009, nr 4, poz. 17, Warszawa.

26. Rozporzqdzenie Ministra Edukacji Narodowej z dnia 8 czerwca 2009 r. w sprawie dopuszczania do użytku w szkole programów wychowania przedszkolnego i programów nauczania oraz dopuszczania do użytku szkolnego podręczników, DzU nr 89, poz. 730, Warszawa.

27. Surdej A., 2003, Chapter 9. Entrepreneurship SME Development in Poland: Policy and Sustainability, in McIntyre, R.J. \& Dallago, B. (eds), Small and Medium Enterprises in Transitional Economies, Palgrave Macmillan, London, s. 98-113, 139-156.

28. Surdej A., Wach K., 2007, Small and Medium-sized Enterprises in Poland, „ERENET Profile”, vol. II, no. 4, s. 9-13.

29. Śleszyński P., 2007, Gospodarcze funkcje kontrolne w przestrzeni Polski, Instytut Geografii i Przestrzennego Zagospodarowania im. S. Leszczyckiego PAN, „Prace Geograficzne”, nr 213, Warszawa.

30. Tobolska A., 2004, Zmiany wtasnościowe i organizacyjno-ekonomiczne w wybranych duzych przedsiębiorstwach przemysłowych Poznania w okresie transformacji, Wyd. Naukowe Bogucki, Poznań. 
31. Tobolska A., 2006, Strategie globalne a nowe formy organizacji przedsiębiorstw transnarodowych [w:] Rola przedsiębiorczości w podnoszeniu konkurencyjności społeczeństwa i gospodarki, Z. Zioło, T. Rachwał (red.), „Przedsiębiorczość - Edukacja”, nr 2, wydawnictwo Nowa Era, Zakład Przedsiębiorczości i Gospodarki Przestrzennej IG Akademii Pedagogicznej w Krakowie, Warszawa-Kraków, s. $226-235$.

32. Wach K., 2007, Potencjat matych i średnich przedsiębiorstw regionu poludniowego [w:] Rola przedsiębiorczości w aktywizacji gospodarczej, red. Z. Zioło, T. Rachwał, „Przedsiębiorczość - Edukacja”, nr 3, wydawnictwo Nowa Era, Zakład Przedsiębiorczości i Gospodarki Przestrzennej IG Akademii Pedagogicznej w Krakowie, Warszawa-Kraków, s. 35-45.

33. Wach K., 2007, Ksztattowanie postaw przedsiębiorczych w programach nauczania. Stan obecny i proponowane kierunki zmian [w:] Ksztattowanie postaw przedsiębiorczych a edukacja ekonomicz$n a$, P. Wachowiak, M. Dąbrowski, B. Majewski (red.), Fundacja Promocji i Akredytacji Kierunków Ekonomicznych, Warszawa, s. 120-127.

34. Wach K., 2008, Regionalne otoczenie matych i średnich przedsiębiorstw, Wyd. Uniwersytetu Ekonomicznego w Krakowie, Kraków.

35. Zioło Z. 2009, Procesy ksztaltowania się światowych korporacji i ich wplyw na otoczenie [w:] Wpływ globalizacji i integracji europejskiej na transformacje struktur przemystowych, Komisja Geografii Przemysłu Polskiego Towarzystwa Geograficznego w Warszawie, Zakład Przedsiębiorczości i Gospodarki Przestrzennej Instytutu Geografii Uniwersytetu Pedagogicznego w Krakowie, „Prace Komisji Geografii Przemysłu PTG”, nr 12, Kraków, s. 12-31.

36. Zioło Z., 2001, Struktura branżowa i koncentracja przestrzenna wiodacych światowych firm przemysłowych [w:] Problemy przemian struktur przemystowych w procesie wdrażania regut gospodarki rynkowej, red. Z. Zioło, „Prace Komisji Geografii Przemysłu Polskiego Towarzystwa Geograficznego", nr 3, Warszawa-Kraków-Rzeszów, s. 29-41.

37. Zioło Z., 2005, Światowe uwarunkowania rozwoju przedsiębiorczości [w:] Przedsiębiorczość a współczesne wyzwania cywilizacyjne, Z. Zioło, T. Rachwał (red.), „Przedsiębiorczość - Edukacja”, nr 1, Wydawnictwo MiWa, Zakład Przedsiębiorczości i Gospodarki Przestrzennej IG Akademii Pedagogicznej w Krakowie, Kraków, s. 9-15.

38. Zioło Z., 2006, Rola przedsiębiorczości w podnoszeniu konkurencyjności społeczeństwa i gospodarki [w:] Rola przedsiębiorczości w podnoszeniu konkurencyjności społeczeństwa i gospodarki, Z. Zioło, T. Rachwał (red.), „Przedsiębiorczość - Edukacja”, nr 2, wydawnictwo Nowa Era, Zakład Przedsiębiorczości i Gospodarki Przestrzennej IG Akademii Pedagogicznej w Krakowie, Warszawa-Kraków, s. $10-17$.

39. Zioło Z., 2007, Rola przedsiębiorczości w aktywizacji gospodarczej-zarys modelu [w:] Rola przedsiębiorczości w aktywizacji gospodarczej, Z. Zioło, T. Rachwał (red.), „Przedsiębiorczość - Edukacja”, nr 3, wydawnictwo Nowa Era, Zakład Przedsiębiorczości i Gospodarki Przestrzennej IG Akademii Pedagogicznej w Krakowie, Warszawa-Kraków, s. 10-17.

40. Zioło Z., 2008, Ekonomiczne i społeczne uwarunkowania rozwoju gospodarki opartej na wiedzy [w:] Rola przedsiębiorczości w gospodarce opartej na wiedzy, Z. Zioło, T. Rachwał (red.), „Przedsiębiorczość - Edukacja", nr 4, wydawnictwo Nowa Era, Zakład Przedsiębiorczości i Gospodarki Przestrzennej IG Uniwersytetu Pedagogicznego w Krakowie, Warszawa-Kraków, s. 12-23.

41. Zioło Z., 2009, Rola przedsiębiorczości w ksztaltowaniu społeczeństwa informacyjnego, [w:] Rola przedsiębiorczości w ksztaltowaniu społeczeństwa informacyjnego Z. Zioło, T. Rachwał (red.), „Przedsiębiorczość - Edukacja”, nr 5, wydawnictwo Nowa Era, Zakład Przedsiębiorczości i Gospodarki Przestrzennej IG Uniwersytetu Pedagogicznego w Krakowie, Warszawa-Kraków, s. 10-18.

42. Zioło Z., Kamińska W., 1993, Rozwój indywidualnej działalności gospodarczej w województwach przygranicznych Polski Poludniowo-Wschodniej [w:] Czynniki i bariery rozwoju rejonów przygranicznych, red. J. Kitowski, Z. Zioło, Sekcja Gospodarki Przestrzennej Komisji Nauk Ekonomicznych Oddz. PAN w Krakowie, Wydział Ekonomiczny Filii UMCS w Rzeszowie, Instytut Gospodarki Przestrzennej i Komunalnej w Warszawie. Kraków-Rzeszów-Warszawa, s. 99-116.

43. Zioło Z., Piróg S., 2000, Potencjat i struktura indywidualnych podmiotów gospodarczych zlokalizowanych wzdluż drogi E-4 na odcinku Kraków-Przemyśl [w:] Działalność człowieka i jego środowisko. 
Księga ku Czci Profesor Marianny Kozaneckiej w 70. Rocznicę Urodzin, red. Z. Zioło, Wyd. Nauk. Akademii Pedagogicznej, Kraków, s. 355-373.

44. Zioło Z., Rachwał T., red., 2005, Przedsiębiorczość a współczesne wyzwania cywilizacyjne, „Przedsiębiorczość - Edukacja", nr 1, Wydawnictwo MiWa, Zakład Przedsiębiorczości i Gospodarki Przestrzennej IG Akademii Pedagogicznej w Krakowie, Kraków.

45. Zioło Z., Rachwał T., red., 2006, Rola przedsiębiorczości w podnoszeniu konkurencyjności społeczeństwa i gospodarki, „Przedsiębiorczość - Edukacja”, nr 2, wydawnictwo Nowa Era, Zakład Przedsiębiorczości i Gospodarki Przestrzennej IG Akademii Pedagogicznej w Krakowie, Warszawa-Kraków.

46. Zioło Z., Rachwał T., red., 2007, Rola przedsiębiorczości w aktywizacji gospodarczej, „Przedsiębiorczość - Edukacja”, nr 3, wydawnictwoNowa Era, Zakład Przedsiębiorczości i Gospodarki Przestrzennej IG Akademii Pedagogicznej w Krakowie, Warszawa-Kraków.

47. Zioło Z., Rachwał T., red., 2008, Rola przedsiębiorczości w gospodarce opartej na wiedzy, „Przedsiębiorczość - Edukacja”, nr 4, wydawnictwo Nowa Era, Zakład Przedsiębiorczości i Gospodarki Przestrzennej IG Uniwersytetu Pedagogicznego w Krakowie, Warszawa-Kraków.

48. Zioło Z., Rachwał T., red. 2009, Rola przedsiębiorczości w kształtowaniu społeczeństwa informacyjnego, „Przedsiębiorczość - Edukacja”, nr 5, Wyd. Nowa Era, Zakład Przedsiębiorczości i Gospodarki Przestrzennej IG Uniwersytetu Pedagogicznego w Krakowie, Warszawa-Kraków.

Publikacja powstała w ramach projektu „Fit for Business: Developing Business Competencies in School (FIFOBI)" realizowanego przy wsparciu finansowym Komisji Europejskiej w ramach Programu „Uczenie się przez całe życie” (Lifelong Learning Programme), numer projektu 143356-LLP-1-2008-1-DE-KA1KA1SCR). Publikacja odzwierciedla jedynie stanowisko ich autorów i Komisja Europejska nie ponosi odpowiedzialności za umieszczoną w nich zawartość merytoryczną.

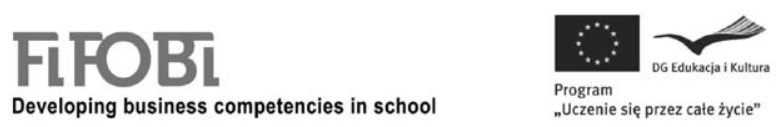

\section{Guidelines and Preliminary Results of European Research Project FIFOBI in the Scope of Developing Competencies Among Pupils in Lower Secondary School [Gimnazjum] for Running Business Activity}

The article aims at the presentation of guidelines and preliminary results of European research project „Fit for Business: Developing Business Competencies in School (FIFOBI)” in developing competencies among pupils in lower secondary school (gymnasium) for running business activity, based on premises associated with modern changes in world economy as well as with changes on the labour market. The analysis of core school curriculum, conducted within the first stage of research work, showed that a Polish pupil ought to be equipped with basic economic knowledge to a relatively large degree. However, it should be noticed that there are significant gaps in developing competences for running own business, particularly in management as well as in social competences, especially connected with solving conflicts and doing teamwork, and in personal competences, associated with entrepreneurial attitude (the records of the core curriculum are narrowed to planning further education and describing traits of an entrepreneurial person). 